University of Wollongong

Research Online

Faculty of Engineering and Information

Faculty of Engineering and Information

Sciences - Papers: Part A

Sciences

$1-1-2013$

Government rail asset sales, and return to the public sector, in New Zealand and Tasmania

Philip G. Laird

University of Wollongong, plaird@uow.edu.au

Follow this and additional works at: https://ro.uow.edu.au/eispapers

Part of the Engineering Commons, and the Science and Technology Studies Commons

Research Online is the open access institutional repository for the University of Wollongong. For further information contact the UOW Library: research-pubs@uow.edu.au 


\title{
Government rail asset sales, and return to the public sector, in New Zealand and Tasmania
}

\author{
Abstract \\ The paper outlines the sale, with a track lease, in 1993 of the state owned New Zealand Railways \\ Corporation to a consortium, TranzRail Holdings formed by the United States and New Zealand interests. \\ It also notes increases in productivity and traffic levels to 1999 with subsequent problems leading to the \\ New Zealand Government agreeing in 2003 to repurchase and rehabilitate the track. The paper then \\ outlines transfer of effective ownership of the trains and related services in 2003 to an Australian \\ company, and in 2008 back to the New Zealand Government at appreciable net cost.After a brief outline \\ of railways in Australia, the paper notes how government rail in Tasmania, then owned and operated by \\ the Australian National Railways Commission, was sold in 1997 with a track lease to a company related to \\ TranzRail Holdings. The paper then notes emerging problems after initial success, and how after a \\ change in ownership in 2004, the Tasmanian track lease was taken back by the public sector in 2007, \\ followed by the trains in 2009. Other rail asset sales in Australia are also noted along with the high total \\ costs of road vehicle operations in Australia and New Zealand.
}

\section{Keywords}

sector, zealand, tasmania, asset, government, sales, rail, return, public

Disciplines

Engineering | Science and Technology Studies

\section{Publication Details}

Laird, P. G. (2013). Government rail asset sales, and return to the public sector, in New Zealand and Tasmania. Research in Transportation Business and Management, 6 116-122. 
Government rail asset sales, and return to the public sector, in New Zealand and Tasmania

Research in Transportation Business \& Management Volume 6 (2013)

Railroad Privatization and Deregulation: Lessons from three decades of

Experience Worldwide

\section{ABSTRACT}

The paper outlines the sale, with a track lease, in 1993 of the state owned New Zealand Railways Corporation to a consortium, TranzRail Holdings formed by United States and New Zealand interests. It also notes increases in productivity and traffic levels to 1999 with subsequent problems leading to the New Zealand Government agreeing in 2003 to repurchase and maintain the track. The paper also outlines transfer of effective ownership of the trains and related services in 2003 to an Australian company, and in 2008 back to New Zealand Government at appreciable net cost.

After a brief outline of railways in Australia, the paper notes how government rail in Tasmania, then owned and operated by the federal Australian National Railways Commission, was sold in 1997 with a track lease to a company related to TranzRail Holdings. The paper then notes emerging problems after initial success, and how after a change in ownership in 2004, the Tasmanian track lease was taken back by the public sector in 2007 , followed by the trains in 2009.

Other rail asset sales in Australia are also noted along with the high total costs of road vehicle operation in Australia and New Zealand.

Key Words New Zealand; Tasmania; Australia; rail asset sales ${ }^{1}$

\section{Introduction}

In 1993, the New Zealand Government sold its rail system with a long term track lease. This was followed in 1997 by the first of many Australian rail asset sales by government.

This article will primarily deal with two rail privatizations in New Zealand and Tasmania that eventually resulted in the respective governments taking back not only the track, but also the trains.

At the outset, it is of note that the two rail systems of New Zealand and Tasmania have relatively small freight tasks. In 1992-93, the New Zealand rail

\footnotetext{
${ }^{1}$ Abbreviations Australian National Railway Commission (ANRC)

Australian Rail Track Corporation (ARTC)

Australian Transport Network Ltd (ATN)

billion net tonne kilometres (btkm)

Bureau of Transport Economics (BTE)

Council of Australian Governments (CoAG)

National Rail Corporation (NRC)

National Transport Commission (NTC)

Pacific National Tasmania (PNT)

Surface Transport Costs and Charges (STCC)

TranzRail Holdings (TRH)

e-mail address: plaird@uow.edu.au.
} 
freight task (prior to sale) was 2.5 billion net tonne kilometres (btkm), and reached 4.2 btkm in 2010-11, also since 1992 the Tasmanian rail freight task has rarely exceeded $0.5 \mathrm{btkm}$. By way of contrast, the Australian rail freight task in 2009-10 (after some 5 years of rapid growth in iron ore and coal exports) was about 259 btkm (Bureau of Infrastructure, Transport and Regional Economics, 2012).

Further information on rail privatisation in Australia and New Zealand may be found in a paper for the World Bank by Williams et al (2005). However, not all people would share in these authors qualified assessment (page 57) that "Overall the rail privatization experience in Australia and New Zealand has been positive..."

Full details of all Australian rail asset sales, plus franchises and track leases, are outside the scope of this paper. Section 2 outlines the New Zealand rail system since the 1980s with the sale by government in 1993 and the taking back of the track in 2004 and the trains in 2008. Section 3 sketches Australian Railways and Section 4 outlines the Tasmania rail system since the 1970s including government taking back the track in 2007 and the trains in 2009. Section 5 briefly comments on some aspects of other Australian rail asset sales, and topics affecting rail freight competitiveness in Australia. This includes the difficult question of road pricing for heavy trucks. The conclusions are given in Section 6 whilst Section 7 addresses implications for managerial practice and public policy.

\section{New Zealand}

Railways in New Zealand go back to 1863 with the former provincial governments. During the 1870s, gauge unification settled on narrow gauge track, and rail expansion with transfer to the central government took place. As noted by Heatley and Schwass (2011), "For much of the 20th century, rail was regarded not only as core government business but also as an iconic part of New Zealand's journey to prosperity"; also, citing Atkinson (2007, p60), the Minister of Railways, Gordon Coates in 1923 noted that "The railways in New Zealand have never been regarded, or run, as a profit-making concern."

The 1970s and 1980s saw both loss of freight and passenger traffic with contraction of the rail system to its present length of about 4000 route $\mathrm{km}$. In 1978 , the $8.9 \mathrm{~km}$ Kaimai rail tunnel was opened, thus cutting the rail distance between Auckland and Tauranga by $52 \mathrm{~km}$ and supporting the later growth of Tauranga as a second port for Auckland. During the 1980s, the central section of the North Island Main Trunk line linking Auckland and Wellington was electrified (at 25000 volts $A C$ ) and upgraded with civil engineering works including deviations.

In 1982, New Zealand Rail was corporatised and faced two major challenges. The first challenge was a view held within sections of Treasury that the railways could be progressively closed down over a period of 15 years. This was on the presumption that the nation's entire land transport task passengers and freight - could more efficiently be handled by road transport.

The second challenge was in 1983 when the Government sought to lift rail protection, which reserved to rail the carriage of most goods moving a distance of more than 150 kilometres. The response of the rail unions to both 
challenges was to embark on a massive Save Rail campaign. This was strongly taken up by the Labor Party in opposition. When Labor won the 1983 election, it was subsequently made clear that rail could stay only if New Zealand Railways was to increase its efficiency and productivity. This was achieved with significant downsizing along with track and other investment to increase productivity. In addition, rail protection for freight was lifted and a mass distance system of road user charges for heavy trucks introduced in the late 1970s was retained, with these charges being increased in 1984.

New Zealand's mass distance charges for heavy trucks have continued to date, albeit frozen for some years, when the New Zealand government was trying to contain inflation. In 2012, for example for a six axle articulated truck with a gross vehicle mass of 45 tonnes the road user charges were about \$NZ0.95 per kilometre. For some details of freight in New Zealand, see for example, Cavana et al (1997).

It is also of note that during the 1990s, New Zealand was examining the potential commercialisation of roads. This involved a major Land Transport Pricing Study with extensive consultation and no fewer than four reports leading to a Road Reform Report (New Zealand Ministry of Transport, 1997) that raised the option of congestion pricing with road charges to reflect the environmental impact of road use. Even though this report was endorsed by the New Zealand Prime Minister, at the end of the day, road pricing reform was stalled, and New Zealand's significant car dependence remains. The impacts are particularly noticeable in Auckland, and are also felt in other major centres.

A Surface Transport Costs and Charges (STCC) study was later commissioned by the New Zealand Ministry of Transport (2005). The study provided data on the costs and charges during 2001-02 for the movement of freight and passengers for road and rail with a view to answering the question "What are the costs of land transport and who is paying them?"

For 2001-02, road vehicle operating costs were estimated at about $\$ 17$ billion. The STCC study included estimates for various external costs. These included additional costs of road accidents not met by insurance $(\$ 670 \mathrm{~m})$ and $\$ 111 \mathrm{~m}$ for environmental costs (including greenhouse gases costed at \$25 per tonne of $\mathrm{CO} 2 \mathrm{e}$ ). The road user and related charges of $\$ 2.63$ billion included Fuel Excise Duty of $\$ 1079 \mathrm{~m}$ and charges from heavy vehicles at $\$ 584 \mathrm{~m}$ (for a freight task of roughly $15 \mathrm{btkm}$ ). The external costs for a rail freight task of about 4 btkm were estimated at a relatively modest $\$ 8.5 \mathrm{~m}$.

In regards to the viability of the rail sector (sub section 5.5) the STCC summary noted:

"At the time of the analysis in 2001-2002, the STCC shows that the rail network as a whole was not financially viable, with a total annual shortfall of $\$ 95$ million per annum. ... Revenues do not cover the cost of upgrading, improving or expanding the rail infrastructure. In order to compete with road freight, there has been downward pressure on prices for rail. The average rate charged by Tranz Rail fell from $12.5 \mathrm{c} / \mathrm{ntkm}$ in 1993 to $10 \mathrm{c} / \mathrm{ntkm}$ in 2000 - a nominal fall of $20 \%$."

After noting less than full total cost recovery from both road and rail freight, the report (sub section 5.5) found: 
"... that if the prices paid by commercial vehicles to use the roading network were raised to cover more of the costs they generate, this could support a shift of suitable traffic to rail which in turn, would be likely to increase the overall financial viability of rail. The alternative to such a policy, given the Government's stated intention to retain the rail network, is long term and continuing subsidies to the rail network."

\subsection{Sale and initial success}

On 17 December 1992, within the scope of existing legislation, the New Zealand Government announced its intention to undertake a formal privatisation process of New Zealand Rail Ltd. A competitive bidding process then followed, involving six bids. A merchant bank,Fay Richwhite and Company Ltd, which had previously been an advisor to New Zealand Rail Ltd, formed a consortium, including with Wisconsin Central Transportation Company and Berkshire Partners LLC (a United States private equity company), to be a bidder in the sale process. The consortium, later called TranzRail Holdings (TRH), was the successful bidder with an agreement for sale and purchasebeing made on 20 July 1993.

On 30 September 1993, New Zealand Rail Ltd was sold for NZ\$400 million to TranzRail Holdings with a lease from the Crown (government) to occupy certain land for railway purposes. TRH became a listed company in June 1996 in New Zealand and the United States to raise $\$ 175 \mathrm{~m}$ to retire post sale acquired bank debt. In New Zealand, ordinary shares were offered at NZ\$6.19 each and including dividends saw a 26 per cent return on investment in the first year. Later the shares reached $\$ 9$ each.

The initial increase in share value in part reflected the 1996-97 freight task increasing to 3.2 btkm (from 2.5 btkm in 1992-93) and modest increases in rail and ferry passengers. During 1996-97, TranzRail also acquired 17 used locomotives from Queensland Rail and 61 used passenger carriages from Britain. In addition, new wagons were acquired, including 21 insulated milk wagons (to supply a large North Island factory), coal wagons, and intermodal wagons. Thus, TRH chairman Edward A Burkhardt (CEO of Wisconsin Central who favoured a longer term approach to rail operations) was able to point to "improved results...in a low growth economic environment" whilst Managing Director Francis Small could claim an ability to "sustain and increase growth" (TRH, 1997, p7 and 17 respectively).

Further traffic growth took place and in Australia the Productivity Commission (1999) was also able to observe increases in labour productivity, asset utilisation, and traffic levels since rail privatisation in New Zealand.

\subsection{Emerging problems}

In 1999, a new chairman (Robert $\mathrm{H}$ Wheeler also of Wisconsin Central) and Managing Director (Michael Beard) were appointed to $\mathrm{TRH}$.

The next few years were to see increasing difficulties for $\mathrm{TRH}$ with a slight fall in the freight task (from a record 4.1 btkm in 1999-2000) and a larger fall in freight revenues with increasing competition from road freight operators. In addition, there was competition to TRH's interisland freight and passenger services. In 2001, the payment of dividends was suspended (8.5 cents per 
share had been paid each six months up to April 2001) and a fall in share price was under way.

In February 2002, Wisconsin Central (which by then had been acquired by Canadian National) and Fay Richwhite sold their controlling stake in TRH. By May 2002, shares had fallen to their then lowest value of \$NZ2.35.

Strong restructuring initiatives were put in place by $\mathrm{TRH}$; as noted by $\mathrm{Mr}$ Beard at a July 2002 special briefing for analysts, fund managers and the media (Rails, 2002), these measures included "a massive restructure, outsourcing engineering functions and divesting non-core business to concentrate on freight." This included sale in 2001 of part of the Tranz Scenic long distance passenger services to an experienced Australian rail passenger operator West Coast Railway, which resulted in the retention of three services, Auckland-Wellington, Christchurch-Greymouth (TranzAlpine) and Christchurch-Picton (Tranz Coastal) along with withdrawing other services.

Some relief to TRH was provided in 2002 by the New Zealand Government agreeing to pay $\$ N Z 81 \mathrm{~m}$ to take back track and trains centred on the Auckland urban area. These trains were later run, under contract, for the Auckland Regional Council. However, TRH's share price continued to fall and reached a low of NZ\$0.39 in mid 2003.

Also, in 2002, when the TRH share price was falling, the New Zealand Securities Commission launched insider trading proceedings against six parties, being Michael Beard, Mark Bloomer, former chief financial officer of TRH, Berkshire Fund III, a former Tranz Rail shareholder and former director Carl Ferenbach (all settled by March 2006) and in June 2007 Midavia Rail Investments Ltd and David Richwhite agreeing to pay $\$ 20$ million, (with all settlements in the case amounting to over $\$ 27.5$ million) without any admission of liability (New Zealand Herald, 2007). Gaynor (2008) estimates that the four main original investors realized profits of $\$ 370 \mathrm{~m}$ from the sale of their TRH shares.

By 2001, many people were beginning to question New Zealand rail privatisation. A TV One (2001) documentary 'Assignment' that went to air on 25 October 2001 noted that eight years on, there had been both winners and losers in the privatisation of rail. As then seen by Greens Co-Leader Rod Donald MP (of a minority parliamentary party) "We gave away rail at a ridiculous price." On the programme, Winston Peters MP went further "It was a terrible rip off then and it has been seen as that now" (Rails, 2001).

In addition, there was then growing support for a Green party view (released 27 March 2001) that a new state owned enterprise should be set up to take over ownership of the track and other infrastructure leaving TRH to move freight and other operators to move passengers. The formation in 2002 of Network Rail in the United Kingdom with the effective collapse of the private company Railtrack (that was responsible for British rail track post privatisation in 1994) provided support for this view, and taking back the track was agreed to by the New Zealand Government in June 2003, with a promise to invest $\$ 200$ million to upgrade the infrastructure. In September 2004, the New Zealand Railways Corporation (Ontrack) was formed by the New Zealand Government and took over the track from TRH for the consideration of \$1. 


\subsection{New owners}

In 2003, following withdrawal of a bid for purchase by Rail America, Toll Limited in NZ (owned by Toll Holdings Pty Ltd of Australia) made a bid of 75 cents for each TRH share. This offer was increased to 95 cents, and later to \$1.10. At the closing date of the higher offer in October 2003, Toll had acquired nearly 84 per cent of TRH. Toll's aim to acquire 90 per cent of the $\mathrm{TRH}$ shares and so be eligible to proceed to compulsory acquisition of the balance of shares was initially frustrated by three institutions and many small New Zealand share holders.

The introduction of Toll (with a strong track record of profits and growth in Australia) and the government taking back the track provided some grounds for optimism, including by Toll, of the viability of rail in New Zealand. As seen by Williams et al (2005, p17) "In our view, the counter-factual to privatization (i.e. continued public sector operation), would most likely have been less successful. It would have been difficult to continue (as the private owner did) the efficiency improvements and increased customer focus started in the late 80 s/early 90 s under public ownership."

This view prevailed, although in hindsight, it may have been cheaper for the New Zealand Government to have bought in 2003 the entire rail system. Toll then set about with a will to improve freight operations, and renamed $\mathrm{TRH}$ as Toll NZ. In turn, the share price started to recover.

In 2007, Toll, reached agreement with Third Avenue, a New York investment firm (who had purchased just over 10 per cent of Toll NZ at an average cost of $\$ 1.63$ a share (Gaynor, 2008) to pay $\$ 3.00$ per share. Toll then proceeded to compulsory acquisition of the balance. This share price valued the company at $\$ 700 \mathrm{~m}$.

In 2004, Toll NZ took back the intercity trains. However, in mid 2006, Toll proposed, in the absence of a government subsidy, to withdraw the Auckland - Wellington passenger train service. This led to a storm of protest and extra passengers with people anxious to ride the historic and scenic train route before services were withdrawn. On the last week of scheduled operation, in September 2006 and without any subsidy, Toll agreed to continue to provide the service, albeit with fewer trains.

By 2008, Toll was actively seeking lower track access fees. As noted by the then managing director David Jackson (2008):

"We have taken no dividends, we have improved the efficiencies, we have motivated staff and we have a business that is now viable...(however), road transport in itself does not carry its full costs. There is no recognition of road operators receiving a subsidy but arguably they do. Rail operations the world over do not meet their costs and require significant subsidization."

Although this claim regarding subsidization may have applied to Toll NZ with its modest freight and small passenger task, it did not apply to large rail fright operators including North American Class I railroads, Australia's iron ore rail haulage, and many larger passenger operators.

As noted by Briginshaw (2008, p2), although Toll NZ had initially agreed to pay to Ontrack (formed in 2004) \$NZ56m for track access charges, and this was upheld by arbitration in preference to a later offer by Toll NZ to pay 
\$NZ48m, the government "was very unhappy at being forced to subsidize a foreign private company" and initially offered to buy Toll Rail for $\$ 500 \mathrm{~m}$.

\subsection{Buy back and rebuilding}

In May 2008, Toll NZ agreed to sell their rail operations to the New Zealand Labour Government for \$NZ665m plus other considerations including payment of some debt incurred by Toll. Although the decision was welcomed by two minority parties (Greens and New Zealand First), the leader of the Opposition and National Party, John Key MP (who became Prime Minister following an election and change of government in November 2008) opposed the decision. So also did a former Labour Minister for Transport, Richard Prebble. From an international perspective, Briginshaw (2008) suggested that it would have been better to have the rail services operated as a concession, rather than the government to become (again) a rail freight operator, and noted "All too often governments make decisions without thinking through the consequences."

Gaynor (2008), noting that since 1990 the New Zealand government "spent or committed nearly $\$ 4$ billion on rail in the debt write-offs, equity injections, asset buy-backs, subsidies, grants and planned track expenditure," asked if this money would have been better spent on the road network.

This amount would include the $\$ \mathrm{NZ400m}$ sale price in late 1993 being some $\$ 559.6 \mathrm{~m}$ in mid 2008 terms Reserve Bank of New Zealand (2012), being more than offset by direct government outlays exceeding $\$ 965 \mathrm{~m}$. These outlays comprised the $\$ N Z 81$ million outlaid in 2002 (about $\$ 95.5 \mathrm{~m}$ in 2008) to repurchase part of the Auckland network, the $\$ 200 \mathrm{~m}$ committed in 2003 for track rehabilitation, and the repurchase cost of $\$ 665 \mathrm{~m}$ in June 2008.

Following the return of the country's rail operation to public ownership on July 12008 and its relaunch as KiwiRail, Prime Minister Helen Clark MP noted, rising oil prices and that:

"It should be acknowledged that Toll Holdings has made good progress in our rail system in recent years. But it also has become clear that our rail system cannot survive without substantial Government subsidies into the future. That, together with the need to develop a more sustainable and integrated transport system for our country, makes the case for public ownership compelling in the 21st Century" (KiwiRail 2008a).

The Deputy Prime Minister and Treasurer, Dr Michael Cullen went further and stated:

"The selling of our rail system in the 1990s was followed by asset stripping and a failure to properly invest in the services. At a time of high petrol prices and concern about climate change, New Zealand cannot afford a substandard rail system."

"We also need to invest more in our rail infrastructure so we can see rail makes its full contribution to the sustainable, modern transport sector our economy needs" (KiwiRail 2008b). 
A New Zealand Treasury perspective is provided by Wilson (2011) who notes, inter alia, that:

"A view that rail freight could be commercially viable proved optimistic...Ultimately the rail system reverted to government ownership and public funding because although Tranz Rail and Toll faced hard budget constraints, the public, including significant parts of the business community, did not find the consequences of the hard budget constraint acceptable."

In its first annual report, for 2008-09, KiwiRail noted reintegration of the above and below rail operations on 1 October 2008 and the movement of about $14.4 \mathrm{~m}$ tonnes of freight with a freight task of 3.96 btkm (down from 2007-08); and measures to increase rail freight (including over $700 \mathrm{~m}$ litres of milk and the commissioning of new container flat wagons and ordering new locomotives). The ongoing upgrading of Auckland and Wellington passenger services (with respective patronages of $7.65 \mathrm{~m}$ and $11.9 \mathrm{~m}$ in 2008) and operation of interisland ferry services (three ships) were also noted.

The 2009-10 KiwiRail (2010) Annual Report, whilst noting no increase in the freight and passenger task, was able to report further upgrading of the Auckland and Wellington urban rail networks, and following development of a 10 year strategic plan estimated to cost $\$ 4.6$ billion, government support for a Rail "Turn around plan" to include growing the rail freight task with an investment by government of $\$ 750 \mathrm{~m}$ over three years.

By 2010-11, KiwiRail was able to report a modest increase in the freight task (about 4.2 btkm) with more revenue (nearly $\$ N Z 400 \mathrm{~m}$ ). Wellington metro network upgrades on several fronts were completed to be ready for new Matangi electric passenger trains (1500 volts DC). Good progress was made towards Auckland's urban rail track upgrading and electrification at 25,000 volts AC due in 2013-14 at a total cost of about $\$ 1.6$ billion. However, in part due to two major earthquakes near Christchurch (in September 2010 and February 2011 with numerous aftershocks), both long distance train and interislander passenger numbers were down from 2009-10.

Auckland's urban rail services, which are now operated by an expanded Auckland City Council (formed in 2010 after amalgamation with other Councils) have seen significant increases in patronage. This is now approaching $11 \mathrm{~m}$ passengers per year; some 12 years ago, it was only about $2 \mathrm{~m}$ per year. Electric trains operated by the Greater Wellington Regional Council had $11.3 \mathrm{~m}$ passengers in 2011-12, with more expected in 2012-13.

\section{Australian railways}

Railways in Australia go back to the 1850s. At the time of Australian Federation in 1901, private railways were limited in extent and there were six State rail systems. Commonwealth Railways were formed in 1917 to operate a line in the Northern Territory and the Port Augusta to Kalgoorlie railway. Australia continues to operate trains, using three main different railway gauges (broad (1600 $\mathrm{mm}$ or $\left.5^{\prime} 3^{\prime \prime}\right)$, standard (1435 $\mathrm{mm}$ or $\left.4^{\prime} 8.5^{\prime \prime}\right)$ and narrow (1067 $\mathrm{mm}$ or $\left.\left.3^{\prime} 6^{\prime \prime}\right)\right)$.

In 1975, legislation provided for the formation of the Australian National Railways Commission (ANRC) to take over Commonwealth Railways and 
operate rail services in South Australia and Tasmania. This occurred in 1978. In 1991, a National Rail Corporation (NRC) was formed following an intergovernmental agreement to provide interstate rail freight services, and jointly owned by the Federal, New South Wales, and Victorian Governments. By 1995, rail freight services were provided by six government operators and several private companies. The six government rail systems then comprised ANRC, NRC and the four State systems of Queensland, New South Wales, Victoria and Western Australia, with an aggregate freight task of about 62 billion tonne kilometers (btkm). Of this, some $28 \mathrm{btkm}$ was due to the haulage of coal. In 1993-94, Australia's Government rail systems had an aggregate rail freight loss of some $\$ 200$ million (Bureau of Industry Economics, 1995). The main private operators in 1995 were iron ore railways in the Pilbara region of Western Australia with a combined freight task of $47 \mathrm{btkm}$.

By 1998, with increasing productivity and micro-economic reform, three government rail freight systems losses had become profitable. This was one factor leading to rail freight privatisation. A further factor was the implementation of National Competition Policy driven by the Council of Australian Governments (CoAG) which required, inter alia, third party access to Government rail track (Productivity Commission 1999, Scrafton 2001, and Owens 2003).

The first sale of government rail assets in Australia was initiated by the Australian (Federal) Government in 1997, and comprised the Tasmanian rail system (TasRail), South Australian intrastate freight operations, and, interstate passenger trains, all formerly owned and operated by ANRC. A 1997 intergovernmental agreement led to the formation of a federal Australian Rail Track Corporation (ARTC) to take over ANRC's interstate track, and to lease interstate mainline track from Victoria, New South Wales and Queensland. This was followed by rail privatisation, with track leases, by the State Governments of Victoria (1999) and Western Australia (2000). In February 2002, NRC and the New South Wales Rail Freight (above rail) operations were sold together to Pacific National; which was then jointly owned by two Australian listed companies, Patrick and Toll.

Along with Williams et al (2005), further details of Australian rail privatisation are also given by the Bureau of Transport and Regional Economics (2006) and the Bureau of Infrastructure, Transport and Regional Economics (2012). For an account of rail freight operations in Australia by this writer to 1995, and more recently to 2007 , see Laird (1998 and 2009).

\section{Tasmania}

When finally acquired in 1978 by the Australian National Railways Commission (ANRC), the Tasmanian Government Railways was a run down system whose main purpose was to freight as passenger services were being eliminated. The ANRC's main challenge was to integrate the former South Australian and Commonwealth rail systems, and to improve operational and financial performance. This included reducing significant rail deficits.

At an early stage, ANRC formed a TasRail unit to operate the Tasmanian rail system. The freight task, due both to limited tonnages and relatively short distances, was (and continues to be) small. As such, the question was often 
asked as to whether the entire system should be closed down, transferring all land freight to trucks. This question was indeed addressed in two studies by the Bureau of Transport Economics (BTE -1987 and 1991). In each study, the conclusion was reached that after consideration of all costs, including that of the road system costs and of external costs, rail freight services were worth retaining in Tasmania. As noted (BTE, 1991, pxvi),

"A full or partial closure of TasRail would further increase heavy truck volumes and this would, among other things, accelerate road damage. It is estimated that closure of TasRail would affect 967 kilometres of road sections and result in increased road reconstruction and maintenance costs... On balance the social cost-benefit analysis suggest that society would benefit from retention of TasRail. However, the full realisation of potential benefits available would depend on a restructuring of TasRail...."

In addition, each of the two studies had recommendations for improving the efficiency of rail operations over some $787 \mathrm{~km}$ of track. This included the 1991 report noting a downward trend of rail deficits (from $\$ 41.9 \mathrm{~m}$ in 1977-78 to $\$ 16.5 \mathrm{~m}$ in $1989-90$ with a freight task varying from about $0.24 \mathrm{btkm}$ to 0.46 btkm).

The improved performance of TasRail by ANRC reflected (BTE, 1991, p1) "provision of modern locomotives (some purchased for Queensland Railways) and rolling stock, ...track rehabilitation, modernisation of maintenance facilities, ...changes in operating practices" along with a considerable reduction in staff numbers. As noted (p10) "The primary goal for TasRail is to achieve break-even by 1995-96, that is covering accounting costs including interest and depreciation."

The 1991 BTE report also included a detailed financial analysis of TasRails past performance and its future prospects to 2010 prepared for the BTE by Fay, Richwhite Australia Limited.

\subsection{Sale and initial success}

In 1995, due to an expanding role for the National Rail Corporation (NRC), ANRC's role and function was changing. In March 1996, after a change of federal government, a review of both ANRC and NRC was commissioned. The review, conducted by Mr John Brew recommended, in part, a break up of ANRC with part privatisation and the formation of a Track Access authority. In respect of Tasmania, Brew (1996) in part recommended transfer of the Tasmanian railway system to private short line operators, or if this was not achievable, then transfer to the Tasmanian Government. Brew $(1996$, p58) also noted recent loss of freight traffic from rail to road, and that "TasRail's current and projected operating results indicate that it is not a profitable business."

The federal government then proceeded to sell TasRail along with two other parts of ANRC. This sale process required new legislation, and an inquiry by a Senate Committee (1997, para 7.41) which recommended that "before proceeding with the sale process, the government should develop a coherent land transport policy framework, taking into account financial, economic, social and environmental goals and recommending mid and long term investment programs for road and rail in all major corridors." 
During parliamentary debate, the need to improve the nation's rail system as well as the option of letting TasRail revert to the Tasmanian Government, was canvassed. Instead, on 28 August 1997, agreements were signed including for the sale of TasRail Pty Ltd (then a subsidiary of ANRC) to Australian Transport Network Ltd (ATN) for \$22 million, with operational railway land transferred to the Tasmanian Government with ATN granted a 50 year lease of the land (Australian National Audit Office, 1998, who also examined the sale process and made seven recommendations). The sale was completed on 14 November 1997, with the sale agreement committing ATN to capital expenditure of $\$ 20 \mathrm{~m}$ over a four year period.

ATN was formed by Wisconsin Central who held a one third interest in ATN, whilst TransRail Holdings held a two thirds interest. Like TRH in New Zealand, ATN was initially able to grow the Tasmanian rail freight task. To assist with this growth, some locomotives were moved from New Zealand to Tasmania, and two lines were reopened. As noted (Productivity Commission, 1999, p147), Tasrail reported an operating profit for its first 7 months of operation, which was for "...the first time in 130 years."

\subsection{Ownership changes}

In 2001, when Canadian National acquired Wisconsin Central, it then set out to dispose of its rail assets in Tasmania as well as New Zealand. The sale of the Tasmanian rail system took over two years, when it was acquired, in February 2004, by Pacific National, who formed Pacific National Tasmania (PNT). This acquisition was not opposed by the Australian Competition and Consumer Commission (2004) who in a statement noted that "the acquisition was unlikely to substantially lessen competition in any market...(also) that there was only one significant freight rail operator in Tasmania, and that this would remain the case after the acquisition..."

Later in 2002, the new owners acquired the privately owned Emu Bay Railway (the $130 \mathrm{~km}$ Melba line). However, by 2005, there were indications that not all was well with PNT. By then, the entire network had a permanent $60 \mathrm{~km} / \mathrm{h}$ speed restriction, for all trains at all times, plus numerous speed restrictions around tight radius curves and over older bridges. On each line there was no shortage of temporary speed restrictions reflecting a variety of track maintenance problems. The axle load limit was 18 tonnes as against 25 tonnes on mainline track in mainland Australia or 30 tonnes on the coal lines of the Hunter Valley of NSW. The track was clearly substandard.

In October 2005, PNT announced that it would cease freight rail services in Tasmania (other than for cement from Railton to Devonport, a distance of $22 \mathrm{~km}$, and minerals on the Melba line) unless financial assistance was provided by the Federal and Tasmanian Governments to upgrade the network (Tasmanian Department of Infrastructure, Energy and Resources, 2007). In addition, a 2005 study had found that "the forced shift of freight from rail to road in Tasmania as a result of rail services ceasing to be available would have resulted in: additional direct costs of more than $\$ 17$ million per annum to the Tasmanian businesses that rely on rail; externalities of more than $\$ 6$ million per annum; and additional road maintenance costs of over $\$ 1$ million per annum." 
Following negotiations, on 1 January 2007, the Tasmanian Government acquired all rail tracks (other than the Melba line) and below rail assets for the sum of $\$ 1$. At the same time, the Australian Government agreed to provide $\$ 78 \mathrm{~m}$ to upgrade the Tasmanian Rail network as part of a Rail Rescue Package, and PNT agreed to provide above rail services on the network and upgrade locomotives and rolling stock along with making provision for any other accredited rail operator to use the network at agreed rail access fees.

\subsection{Buy back}

Following further negotiations and passage of the Rail Company Act 2009, the Tasmanian Railway Pty Ltd, trading as TasRail and owned by the Tasmanian Government, was established as a vertical integrated freight railway to operate rail freight services formerly offered by PNT. The purchase price was $\$ 32 \mathrm{~m}$, comprising $\$ 26 \mathrm{~m}$ for locomotives and rolling stock plus workshops and other buildings and $\$ 6 \mathrm{~m}$ for an ore shiploader at the port of Burnie. In addition, the Melba line was also acquired, the Australian Government agreed to provide funding to $2013-14$ amounting to $\$ 126$ m (for capacity improvement and capital upgrades) to supplement the $\$ 78 \mathrm{~m}$ rail rescue package, and, the Tasmanian Government committed $\$ 40 \mathrm{~m}$ over 10 years. The additional funding was to allow for replacement of locomotives and wagons (at the end of their economic life) as well as a new $\$ 4 \mathrm{~m}$ train control centre (Tasrail, 2011a).

On 13 December 2011, a contract was signed for $\$ A 607 \mathrm{~m}$ to acquire $17 \mathrm{new}$ locomotives to replace the existing "life expired fleet" (TasRail 2011b). In addition, two new rail intermodal freight services were started in 2012 and four locomotives were acquired from Queensland to meet this increase in business.

Tasrail moved about $2.3 \mathrm{~m}$ tonnes of freight in $2010-11$, earning $\$ 31 \mathrm{~m}$ and making a small operating profit but incurring an overall loss of $\$ 4.6 \mathrm{~m}$, so there is some way to go from "Rail Rescue" to that of a of "Rail Resurgence" (TasRail 2011b). However, the Tasmanian Government has a clear vision "for a viable rail network as part of an efficient land transport system."

Moreover, as previous studies have found transport costs to users of land freight services, road system costs, and external costs would increase if the Tasmanian Rail system was to close.

TasRail (2012) reported in 2012 an impairment expense of $\$ 31.7 \mathrm{~m}$ and a total comprehensive loss of $\$ 36.3 \mathrm{~m}$ with its operations in moving some $2.34 \mathrm{~m}$ of freight during 2010-11, taking the equivalent of 100,000 B-Double (large) truck movements off the roads and reducing greenhouse gas emissions by over 46,000 tonnes. The loss is regarded by management as a turning point in rehabilitating rail in Tasmania. However, as seen by an opposition spokesman Hidding (2012), which aptly summarizes the Tasmanian situation: "If publiclyowned monopoly businesses lose money, how on earth are Tasmanian businesses in the private sector supposed to make a quid?" 


\section{Recent changes in Australia}

Subsequent to the World Bank sponsored review (Williams et al, 2005), the changes to ownership of railways in Australia have included:

* transferring of Victoria's below rail assets including a track lease (acquired from Freight Australia in 2004) from Pacific National in May 2007 to the Victorian Government, for a consideration of $\$ 133.8$ million.

* change in ownership of Pacific National in 2007 from Patrick and Toll to a new listed company called Asciano.

* part of Queensland Rail, including some track and coal trains, being sold in November 2010 as QR National as an Initial Public Offering.

* Genesee and Wyoming Inc completing in December 2010 the acquisition of the assets of FreightLink Pty Ltd including a 50 year lease on the $1420 \mathrm{~km}$ Alice Springs to Darwin railway (completed in 2003) that was placed in receivership in November 2008.

In addition, it is of note that in December 2002, following the cessation of National Express trains operations in Victoria, their regional passenger train franchise was transferred back to the public sector, whilst their Melbourne tram and train franchises were transferred to other franchise holders.

\subsection{Some outstanding Australian rail issues}

Along with under-investment in interstate mainline track linking Australia's three largest cities and regional Australia (see, for example, a Rail Projects Taskforce, 1999, a House of Representatives Standing Committee, 2007, and Laird, 1998 and 2011), and the ongoing multiplicity of railway gauges in Australia, the performance of the Australian rail freight industry in the non bulk sector has also been impeded by a multiplicity of state based regulators. A good background paper on rail regulation is given by the BTE (2006).

Progress on regulatory reform has been slow despite a Productivity Commission (2006) freight report noting the need for '....achieving a nationally consistent approach to access and regulation of the rail sector,' Australia having a National Transport Commission (NTC) since 2004, and various Council of Australian Governments (CoAG) agreements. However, following an intergovernmental agreement, Australia is to have a National Rail Safety Regulator as of 1 January 2013.

A further factor affecting rail freight competitiveness is road pricing for heavy trucks. Here, charges are set on a national basis by the Australian Transport Council comprising Australia's many ministers of transport as recommended by NTC by way of a 'determination'. The NTC charges were subject to an inquiry by the Productivity Commission (2006) that in part endorsed the NTC methodology whilst noting that it is "conservative" by international standards (i.e. resulting in lower charges). Elsewhere, this writer (Laird, 2006) has argued under-recovery of road system costs from articulated trucks was then about $\$ 1.5$ billion per annum, with other external costs of a further $\$ 1.5$ billion per annum.

In May 2010, a major Review of Australia's future tax system (see http://taxreview.treasury.gov.au) made several pertinent recommendations for 
road pricing reform. These included that CoAG "should accelerate the development of mass-distance-location pricing for heavy vehicles..."

However, progress towards competitive neutrality for road and rail track access pricing for trucks and freight trains continues to be slow.

As observed by Patterson (1999) and noted by Scrafton (2001), "rail and sea transport are not achieving their potential in the current system, while road and air transport are over-used to compensate. The result is a system that inflates national costs and energy use."

As noted (Laird, 2011), road vehicles used about 31 billion litres of fuel during 2011; and a more efficient and competitive rail systems coupled with selected rail investment on current networks (excluding High Speed Rail currently under examination by the Australian Government) and road pricing reform has the potential to reduce liquid fuel use by 2.5 billion litres per year.

\section{Findings and discussion}

It is clear that the New Zealand Government in selling in 1993 its rail system and the Australian Government in selling TasRail in 1997 to the private sector incurred many subsequent costs to government.

Both rail systems with their new private sector owners were initially able to grow freight traffic. However, as highways continued to be upgraded with more and heavier trucks competing for freight, and the cost of maintaining rail track to a good standard began to become a burden, problems started to emerge. With Wisconsin Central as a major shareholder in both systems and then onselling the two rail systems to Canadian National, the problems were not addressed. In each case, the initial solution was for the relevant governments to "take back the track"; New Zealand in 2004 and Tasmania in 2007. Despite this giving some improvement in rail finances and prospects, both rail systems reverted to full government ownership (in 2008 and 2009 respectively).

Provision of rail freight services can confer wider environmental and social benefits, and in some cases may be regarded as a Community Service Obligation. The alternative of putting such rail freight onto road, when all costs are considered, can be a costly option. However, if rail subsidies are to be paid, the question arises as to whether they should be paid to a private sector provider or a government agency. The experience, at least in the New Zealand and Tasmanian cases, suggests that the subsidies may better be directed to a government agency, charged with the responsibility of providing efficient and cost effective rail freight (and passenger) services.

In the Tasmanian case, given a much smaller freight track, a decision by government that the rail system should be retained, and the rehabilitation required, it is considered appropriate that it continue to be government owned. In this case, the owner since 2009 has been the Tasmanian Government, who relinquished its rail system in a 1975 agreement to the Australian Government.

Clearly, private companies have a duty to look after their shareholders interests. However, the experience of rail asset sales in both New Zealand and Tasmania does highlight a latent failure of privatising inherently loss making activities that are for the 'public good'. 
A further dimension to public ownership, made explicit in 2008 by the New Zealand Government, is rail's superior energy efficiency when compared to road freight, and its ability to reduce greenhouse gas emissions.

\section{Implications for managerial practice and public policy}

Operating a national rail system presents challenges on many fronts. These challenges include not only day to day train operations but also securing sufficient revenue for track maintenance. The ability to generate revenue from rail freight in many countries, including Australia, is often compromised by rails major competitor of road freight operating over public infrastructure with arguable low rates of road cost recovery. However, even in New Zealand, with heavy trucks paying mass distance based pricing, problems surfaced after the first seven years of operation.

The New Zealand, Tasmanian and Victorian experiences with long term rail track leases by government to the private sector, like that in the United Kingdom, has not been a happy one.

From a public policy perspective, although selected rail privatisation in certain situations can confer advantages, in some instances (excluding successful 'short line' operations), it can lend to either a complete loss of service, or, a need for subsidies from government. If privatisation is embarked on, it is necessary to give very careful attention to the conditions of sale or lease. The article suggests that certain low traffic railways may be better retained in public ownership, with conditions to ensure efficient and competitive operations.

In the case of New Zealand railways, privatisation also underscored the challenge of a bidder in part connected to a consultant to the government owned railways prior to their being offered for sale. The article noted the sale price, of $\$ N Z 400$ in late 1993 being some $\$ 559.6$ million in mid 2008 terms (rbnz.govt.nz), being outweighed being more than offset by direct government outlays of $\$ 1320 \mathrm{~m}$ including the remaining repurchase cost of $\$ 665$ in June 2008.

Further research could include an examination of the costs and benefits of the many rail privatisations in mainland Australia that occurred from 1997 to 2010. In some instances, these have provided stern lessons for both government and the private sector. A further question is whether some transport policy reform by government prior to a rail asset sale or lease would improve not only the price paid to government but also the prospect for successful privatisation with adequate returns to the new private owners. There is also the question of incentives for the new owners to invest and grow traffic in challenging areas, including that of non-bulk freight.

\section{ACKNOWLEDGEMENTS}

The author would like to thank Ms Sarah Schachtel of the Faculty of Informatics of the University of Wollongong for research assistance, Professor Derek Scrafton of the University of South Australia and Mr Peter Kain of the BTE for helpful discussions and some references along with Mr John Hoyle, 
former Australian regional editor for International Railway Journal, for comment on the Tasmanian rail network. He would also like to thank two anonymous referees and RTBM Editor Professor Mary Brooks for their comment on a draft of this paper. However the responsibility for the findings and views remains with the author.

\section{REFERENCES}

Atkinson, N., 2007. Trainland: How railways made New Zealand. Random House: Auckland.

Australian National Audit Office, 1998. Sale of SA Rail, Tasrail and Pax Rail.

Brew, J., 1996 Review of Australian National Railways Commission and National Rail Corporation

Briginshaw, D., 2008. Editorial, International Railway Journal, June 2008.

Bureau of Industry Economics,1995. Rail Freight 1995 International Benchmarking, Canberra.

Bureau of Transport Economics, 1978. The Tasmanian Rail System: An Assessment of Costs and Benefits.

Bureau of Transport Economics, 1991. The Future of the Tasmanian Railway System: A Cost - Benefit Assessment of Options.

Bureau of Transport and Regional Economics 2006. Optimising harmonization in the Australian railway industry Report 114.

Bureau of Infrastructure, Transport and Regional Economics 2012. Trainlines I Statistical Report

Cavana, R.Y., Harrison, I.G., Heffernan, F.E.B., and Kissling, C.C., 1997. Freight transport In M. Pickford and A. Bollard (eds.): The Structure and Dynamics of New Zealand Industries. Palmerston North: Dunmore Press.

Gaynor, B., 2008. Government Toll buy a sad indictment, New Zealand Herald for May 10.

Heatley, D. and Schwass, S., 2011. 'Rail Transport in New Zealand' In Christopher Findlay (ed.) The impacts and benefits of structural reforms in transport, energy and telecommunications sectors. Asia-Pacific Economic Cooperation Policy Support Unit, Asia-Pacific Economic Cooperation Secretariat, Singapore.

Hidding, R. (2012) As quoted, TasRail posts big loss, Australian Broadcasting Corporation, http://www.abc.net.au/news/2012-11-05/tasrail-posts-bigloss/4353198?section=tas accessed 6 November 2012 
House of Representatives Standing Committee on Transport (etc) Canberra, 2007. The Great Freight Task: Is Australia's transport network up to the challenge?

Jackson, D., 2008. Rails magazine, September issue.

Kiwirail, 2008a. Staff Newsletter Issue 1, June 112008.

Kiwirail, 2008b. Staff Newsletter Issue 2, July 252008.

Laird, P. G., 1998. Rail freight efficiency and competitiveness in Australia, Transport Reviews, Taylor and Francis, London, Vol 18, pp. 241-256.

Laird, P. G., 2006. Freight transport cost recovery in Australia, Australasian Transport Research Forum, Gold Coast.

Laird, P. G., 2009. Australian freight railways and commodity exports Canadian Transportation Research Forum, Vancouver, Proceedings p. 641.

Laird, P. G., 2011. Railways in Australia: Federation Unfulfilled http://www.parkesfoundation.org.au/Projects_oration2011.htm.

New Zealand Ministry of Transport, 1997. Land transport Pricing Study, Options for the Future.

New Zealand Ministry of Transport, 2005. Surface Transport Costs and Charges (STCC) study.

New Zealand Herald, 2007. Richwhite and Midavia pay \$20m over insider trading case, 18 June.

New Zealand Herald, 2008. Government subsidy is needed to keep rail on track, 17 March.

Owens, H., 2003. Rail reform strategies: the Australian experience, National bureau of economic research, Working Paper 9592

http://www.nber.org/papers/w9592.

Paterson, J., 1999. A National Transport Strategy? Submission to Inquiry into Rail Reform Productivity Commission, pc.gov.au.

Productivity Commission, 1999. Progress in Rail Reform.

Productivity Commission, 2006. Road and rail freight infrastructure pricing.

Rail Projects Taskforce, 1999. Revitalising Rail: The Private Sector Solution, Department of Transport and Regional Services, Canberra.

Rails, 2002. Tranzrail comes out fighting, September, Southern Press Ltd Wellington, p. 28. 
Scrafton, D.,1999. The way ahead: Australian transport in the 21st century. The William Fraser commemorative address to the Chartered Institute of Logistics and Transport in Australia.

Scrafton, D., 2001. Railway reform in Australia: access regimes, changes in ownership and structural reform freight. Canadian Transportation Research Forum Proceedings pp. 761-776.

Senate Standing Committee on Rural and Regional Affairs and Transport 1997. Report on the Brew Report and on the continuing role of the Commonwealth in the Australian rail industry .

Tasmanian Department of Infrastructure, Energy and Resources 2007. Declaration Application to the National Competition Commission, annual report.

TasRail, 2012, Annual Report, at http://www.tasrail.com.au/ accessed 6 November 2012.

Williams, R., Greig, D. and Wallis, I., 2005. Results of privatization of Australian and New Zealand railways, The World Bank Group Transport Paper TP-7.

Wilson, J., 2010. Short history of post-privatization in New Zealand. New Zealand Treasury 1982752v1. Available at: http://www.comu.govt.nz/resources/pdfs/mixed-ownershipmodel/momshppnz-wilson-dec10.pdf, accessed 29 October 2012. 